\title{
PERPECAHAN DALAM GEREJA \\ Ulasan Biblika terhadap 1 Korintus 1:10-13
}

Adi Putra, M.Th.

\section{A. Pengantar}

Sepanjang sejarah gereja, sejak lahirnya hingga sekarang, gereja selalu dan berulang kali jatuh dalam perpecahan. Padahal keinginan Tuhan Yesus terciptanya kesatuan di antara pengikut-Nya. Hal ini dikemukakan oleh Yesus dalam doa-Nya, seperti yang dicatat oleh Yohanes, "Ya Bapa yang Kudus, peliharalah mereka dalam nama-Mu, yaitu nama-Mu yang telah Engkau berikan kepada-Ku, supaya mereka menjadi satu sama seperti Kita" (Yoh. 17:11b). Kesatuan yang dimaksud oleh Tuhan Yesus dalam konteks ini adalah bebas dari konflik, pertengkaran dan sikap mementingkan diri sendiri.

Gereja yang hidup dan dikehendaki oleh Yesus Kristus adalah gereja yang selalu bersatu dan bersinergi menjalankan tugas dan tanggung jawabnya di tengah-tengah dunia. Gereja seringkali diibaratkan perahu yang berlayar di tengah badai yang dahyat. Gereja selalu dituntut untuk bersatu meskipun memiliki fungsi dan tugas yang berbeda-beda. Hal ini juga yang coba diajarkan oleh Paulus kepada jemaat Korintus yang terjebak dalam perpecahan. Paulus mengatakan, "Karena sama seperti tubuh itu satu dan anggota-anggotanya banyak, dan segala anggota itu, sekalipun banyak, merupakan satu tubuh, demikian pula Kristus.." (1Kor. 12:12). Dengan demikian, seyogyanya gereja harus bersatu meskipun memiliki anggota yang beragam dan plural.

Perpecahan pertama pada gereja terjadi pada saat Konsili Efesus (431), yang menyatakan status Perawan Maria sebagai Theotokos (Bunda Allah). Kebanyakan yang menolak hasil keputusan ini adalah Kristen Persia, gereja yang sekarang dikenal sebagai Gereja Asiria Timur.Perpecahan berikut terjadi setelah Konsili Khalsedon (451). Konsili ini menolak monofisit. Kristen yang menolak ini dikenal sebagai Komuni Oriental Ortodoks. ${ }^{1}$

Perpecahan besar pertama dalam Gereja Katolik terjadi pada abad 11. Masalah perbedaan doktrin tentang rumusan Pengakuan Iman Nicea-Konstantinopel dan perebutan kekuasaan duniawi adalah penyebab utamanya. Gereja Katolik pun terbagi menjadi dua, yaitu "Barat" dan "Timur". Inggris, Prancis, Roma dan negara-negara Skandinavia termasuk Gereja "Barat" (Gereja Katolik Roma). Sedangkan Yunani, Rusia, Suriah, Mesir termasuk dalam Gereja "Timur" (Gereja Ortodoks). Perpecahan ini dikenal sebagai Skisma BaratTimur. 2

Skisma Barat atau skisma kepausan yang terjadi dalam Gereja Katolik Roma selama periode tahun 1378 hingga 1417. Pada waktu itu, ada tiga orang yang mengklaim dirinya sebagai Paus yang sah. Menurut informasi yang berbeda bahwa skisma ini terjadi karena dilatarbelakangi oleh kepenting politik dibanding perbedaan dogmatis. Seringkali skisma Barat disebut juga skisma Besar, tetapi istilah ini lebih sering digunakan untuk skisma TimurBarat. Dan berakhir setelah diadakannya Konsili Konstanz (1414-1418). ${ }^{3}$

Ada satu skisma lagi yang sangat terkenal dan begitu membekas hingga saat ini. Skisma ini disebut reformasi Protestan. Tindakan ini merupakan sebuah skisma dari Gereja Katolik yang diprakarsai oleh Martin Luther dan dilanjutkan oleh Yohanes Calvin, Ulrich Zwingli, serta beberapa tokoh reformis Protestan lainnya di Eropa. Skisma ini terjadi sekitar abad ke-16 yang berawal dengan publikasi 95 tesis dari Martin Luther pada tahun $1517 .^{4}$

${ }^{1}$ https://tulussudarto.wordpress.com/2007/09/28/perpecahan-gereja-2/

${ }^{2}$ https://tulussudarto.wordpress.com/2007/09/28/perpecahan-gereja-2/

https://id.wikipedia.org/wiki/Skisma_Barat//

${ }^{4}$ https://id.wikipedia.org/wiki/Reformasi_Protestan// Meskipun sebelum Luther telah ada upaya-upaya awal yang signifikan untuk melakukan reformasi Gereja Katolik - seperti yang dilakukan oleh Jan Hus, Peter Waldo (Pierre Vaudès), dan John Wycliffe - Martin Luther secara luas diakui telah memulai Reformasi Protestan dengan 95 Tesis. Luther mengawali dengan mengkritik penjualan indulgensi, bersikeras bahwa Sri Paus tidak memiliki otoritas atas purgatorium dan bahwa ajaran Katolik mengenai jasa orang-orang kudustidak memiliki landasan di dalam Alkitab. 
Perpecahan terakhir terjadi ketika Raja Henry VIII dari Inggris memisahkan seluruh gereja-gereja di kerajaannya dari persekutuan dengan Paus karena permintaannya untuk menikah kembali sementara istrinya masih hidup ditolak. Kelompok gereja inilah yang dikenal sebagai Gereja Anglikan. ${ }^{5}$

Gereja-gereja di Indonesia juga ternyata diperhadapkan dengan situasi perpecahan atau konflik dan berujung kepada lahirnya satu denominasi baru. Salah satu contoh yang begitu familiar adalah perpecahan dalam gereja HKBP. Sebagai gereja suku terbesar di Indonesia membuat setiap konflik yang terjadi di dalam kepengurusannya tidak dapat ditutupi.

Sekitar tahun 1962, terjadi konflik internal dalam kepengurusan HKBP. Di mana konflik ini cukup riskan dan menggoyang kesatuan dan kekompakan anggotanya. Kekurangserasian sesaama pengurus memuncak. Beberapa pendeta merasa kurang puas atas pelayanan, pengelolaan dan kemimpinan dalam gereja. Berbagai wadah dibentuk dan upaya telah dilakukan untuk mengatasi persoalan ini, namun tidak dapat diselesaikan. Akibatnya terjadi pro-kontra. Namun yang perlu dicermati ialah bahwa konflik itu bukanlah karena faktor teologis. ${ }^{6}$ Menurut berbagai kalangan banyak hal yang menjadi faktor konflik dalam tubuh kepengurusan HKBP dan berujung pada perpecahan gereja. Menurut informasi, akar persoalan muncul ketika seorang warga jemaat biasa, yang juga adalah seorang pengusaha besar, namun memegang jabatan strategis pada struktural di majelis pusat. Ternyata hal itu menimbulkan kekecewaan sebagian pengurus. ${ }^{7}$

Dengan demikian, dapat dilihat bahwa pada umumnya faktor penyebab terjadinya perpecahan dalam gereja adalah lebih dominan disebabkan oleh faktor manusia, kepentingan manusia yang terlalu egois, terlalu serakah dan tidak lagi memprioritaskan kepentingan pelayanan serta motivasi yang benar untuk menggembalakan "kawanan domba Allah".

Hal inilah juga yang coba dijelaskan oleh Paulus kepada jemaat di Korintus dalam 1 Korintus 1:10-13. Oleh karena ternyata di Korintus juga mengalami begitu banyak masalah dan salah satunya adalah ancaman perpecahan.

\section{B. Konteks ${ }^{8} 1$ Korintus 1:10-17}

Gereja di Korintus didirikan pada perjalanan misi Paulus yang kedua, diperkirakan sekitar tahun 52 M, dapat dibandingkan kesaksian Kisah Para Rasul 18:1-18. Kemungkinan besar tinggal di sana selama 18 bulan. Selama menjaga jemaat Korintus, di sana dia juga bekerja sebagai seorang pembuat tenda.

Paulus juga menyebut orang Korintus ‘tidak kekurangan dalam suatu karunia pun'. Dan atas kondisi inilah, jemaat Korintus menjadi sangat bergembira, namun sikap ini juga membuat jemaat di Korintus menjadi sangat congkak, puas diri, sehingga jemaat menjadi kacau.9 Akibat kekacauan ini jemaat di Korintus mengalami ekstase (kegembiraan yang meluap). Ekstase ini ditujukan bukan lagi kepada Kristus, melainkan terhadap perempuanperempuan yang dapat memenuhi hasrat mereka. ${ }^{10}$ Meskipun sebenarnya terjadinya penyimpangan moral di jemaat Korintus berasal dari komunitas Yahudi Gnostik.

Selanjutnya konteks 1 Korintus 1:10-13 tidak dapat dilepaskan hingga 2:1-16. Di mana pada bagian, Paulus menyatakan berbagai persoalan atau masalah yang terjadi dalam jemaat dan disebabkan oleh kurangnya persatuan di antara orang Kristen di Korintus. Mereka

${ }^{5}$ https://tulussudarto.wordpress.com/2007/09/28/perpecahan-gereja-2/

' https://ketarenwydia.blogspot.com/2018/05/makalah-sejarah-berdirinya-gkpi-gereja.html

BA. Simanjuntak, "Budaya Konflik Krisis HKBP dan Kelengahan Strategis”, Gereja Di Pentas

Politik, Binar Sitompul, Rainy Hutabarat (Ed.), (Jakarta: Yakoma-PGI, 1997), hlm. 52.

8 Paradigma yang dibangun dalam membahas tentang konteks ini adalah paradigm vertikal. Oleh karena hanya meneliti konteks berdasarkan pemahaman Surat 1 Korintus dan secara khusus pasal 1-2. Hlm.583-587.

D Douglas. Ensiklopedi Alkitab Masa Kini: Jilid I (A-L), (Jakarta: Yayasan Bina Kasih/OMF. 1992),

${ }_{10}$ D Douglas, hlm. 583-587. 
terpecah ke dalam kelompok-kelompok, yang masing-masing mengklaim mengikuti guruguru ataupun ajaran-ajaran yang berbeda. Paulus memperingatkan mereka bahwa kematian Kristus di kayu salib adalah pusat Injil dan bahwa mereka harus lebih mendengar Roh Allah daripada hikmat duniawi.

\section{Tafsiran terhadap 1 Korintus 1:10-13}

Berdasarkan diagram yang diberikan oleh Leedy, maka ditemukan bahwa masingmasing ayat berdiri sendiri namun tetap dalam kesatuan konteks. Pemahaman ini muncul dalam bagan di bawah ini!

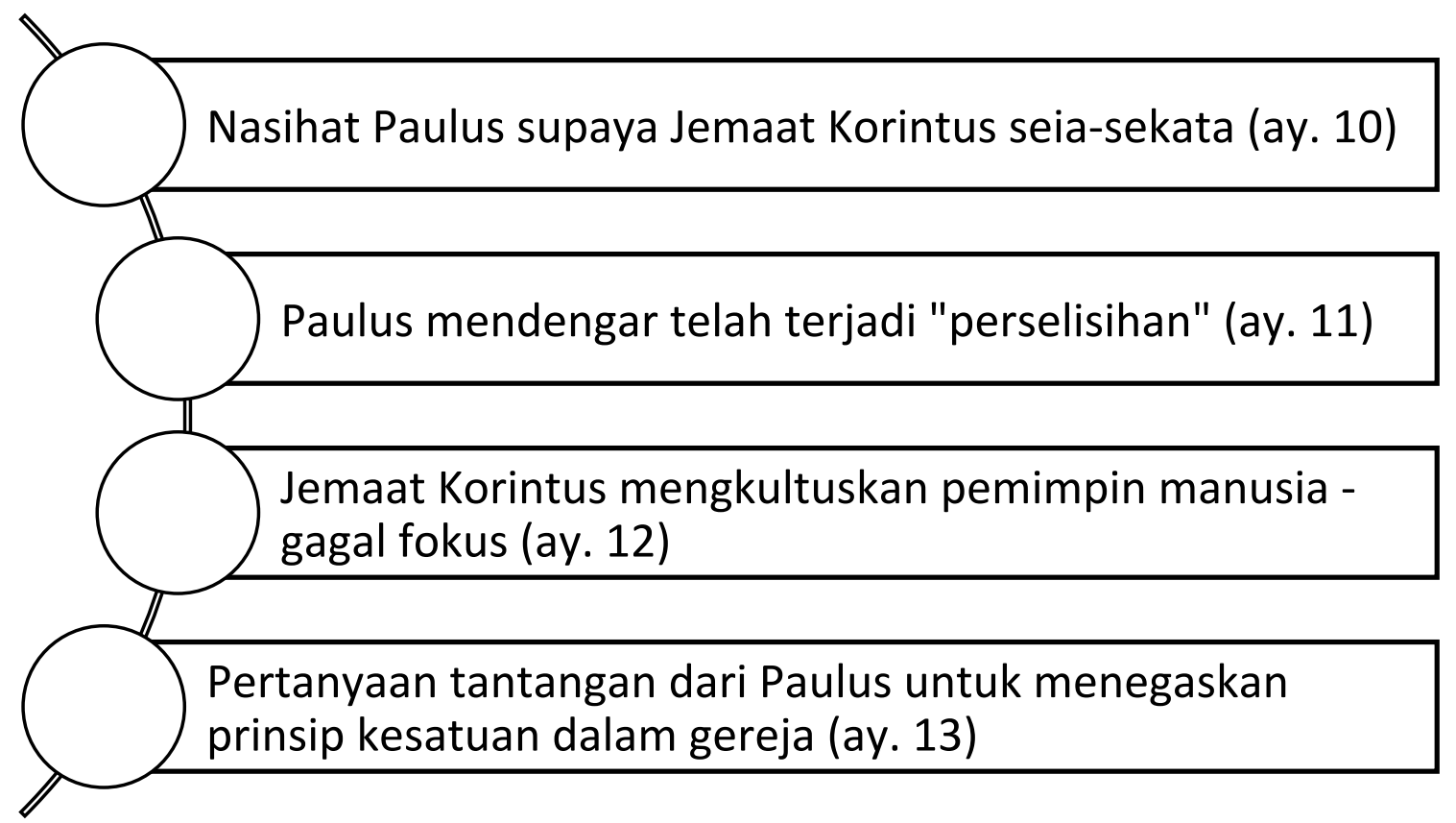

Nasihat Paulus supaya jemaat Korintus seia-sekata (ay. 10). Menurut Pfitzner ungkapan seia-sekata secara harfiah supaya semuanya mengatakan hal yang sama." Ditambahkan Leon Morris, "That all of you agree (more of literally, 'speak the same thing') make use of a classical expression for being united. The use of party cries always tends to deepen and perpetuate division and Paul calls for their abandonment. To 'speak the same thing' can be a first step to real unity, whereas catch cries promote division". ".2 Jadi menurut Morris, melalui ungkapan ini, Paulus hendak memanfaatkan ungkapan klasik untuk menekankan "dipersatukan". Penggunaan kelompok yang berseteru selalu cenderung untuk memperdalam dan mengabadikan perpecahan dan Paul menyerukan pengabaian mereka. Untuk 'berbicara hal yang sama' dapat menjadi langkah pertama menuju persatuan yang nyata, sedangkan tangisan (perseteruan) mempromosikan perpecahan.

Apa yang dikemukakan oleh Pfitzner dan Morris di atas memang saling melengkapi dan sama sekali tidak bertentangan. Akan tetapi apa yang dikemukakan oleh keduanya menjadi sangat jelas dalam pendapat Dean Anderson berikut,

Yang dimaksudkannya bukan terutama agar setiap orang mengakhiri perbedaannya dan memiliki pendapat yang sama tentang setiap pokok, tetapi bahwa mereka harus belajar untuk mengungkapkan apa yang harus dikatakan. Itulah yang membuat mereka menjadi satu kesatuan. Paulus mengarahkan mereka pada inti kesatuan mereka, yaitu Yesus Kristus, Tuhan mereka. ${ }^{13}$ 2008), hlm. 25

${ }^{"}$ V.C. Pfitzner, Ulasan atas 1 Korintus: Kesatuan dalam Kepelbagaian, (Jakarta: BPK Gunung Mulia,

${ }^{12}$ Leon Morris, Tyndale New Testament Commentaries: 1 Corinthians, Grand Rapids, Michigan, 1993), hlm. 39 (Revised Edition). 48.

${ }^{13}$ R. Dean Anderson, Tafsiran Perjanjian Baru: Surat 1 Korintus, (Surabaya: Momentum, 2018), hlm. 
Dengan demikian dapat dipahami bahwa seia-sekata tidak sedang menegaskan bahwa dalam jemaat tidak boleh ada perbedaan pendapat. Namun yang substansi di sini adalah bagaimana masing-masing anggota memahami posisi dan porsi masing-masing serta bagaimana setiap anggota senantiasa "melihat" kepada Kristus sebagai dasar relasi yang telah mempersatukan mereka. Oleh karena apabila hal ini dapat dilakukan maka sebesar apapun perbedaan yang ada dalam jemaat, tidak akan menimbulkan perpecahan. Karena Yesus Kristus tetap menjadi dasar mereka.

Paulus mendengar telah terjadi perselisihan (ay. 11). Berdasarkan informasi dari keluarga $\mathrm{Kloe}^{14}$, maka Paulus akhirnya tahu bahwa dalam jemaat di Korintus telah terjadi "perselisihan" (secara harfiah: pertikaian). Apabila mempelajari surat 1 Korintus dengan baik, maka kita dapat menjumpai bahwa kemungkinan besar jemaat di Korintus terpecah atau berselisih oleh karena mereka saling klaim rasul yang dianggap paling benar dan paling hebat (bdk. ay. 12). Hal ini juga disetujui oleh Dean Anderson dengan mengatakan, "Kesatuan ini terancam oleh pendapat-pendapat yang saling berbeda di dalam jemaat, sehingga menyebabkan terbentuknya berbagai golongan". ${ }^{.5}$ David E. Garland mengatakan,

"Paul has received word from Chloe's people (literally 'those of Chloe') that the church is racked by dissensions (erides, discords, strifes, contentions). The news of them fighting amongst themselves is one of his chief concerns in the letter. Eris refers to 'hot dispute, the emotional flame that ignites whenever rivalry becomes intorable and was well known as something that makes a group vulnerable to attack from outside. The word appears frequently in Paul's listing of vices (Rm. 1:29; 13:13; 2Cor. 12:20; Gal. 5:20; 1Tim. 6:4; Tit. 3:9)" ${ }^{16}$

Berdasarkan pendapat Garland di atas maka dapat dipahami bahwa ketika Paulus menerima kabar dari orang-orang Kloe bahwa gereja sedang dalam pertikaian (erides, perselisihan, pertengkaran), maka berita itu menjadi salah satu keprihatinan utamanya dalam surat itu. Eris (erides) mengacu pada 'perselisihan panas, nyala api emosional yang menyala setiap kali persaingan menjadi tidak menyenangkan dan dikenal sebagai sesuatu yang membuat kelompok rentan terhadap serangan dari luar. Kata itu sering muncul dalam daftar kejahatan dalam surat Paulus (Rm. 1:29; 13:13; 2Kor. 12:20; Gal. 5:20; 1Tim. 6: 4; Tit. 3: 9).

Dengan demikian, dapat dilihat dengan jelas bahwa betapa gentingnya masalah ini. Dan apabila tidak diselesaikan secepatnya dan dengan penanganan yang tepat maka bukan tidak mungkin akan dapat menimbulkan perpecahan. Sehingga keinginan Yesus supaya jemaatnya bersatu tidak akan dapat terwujud.

Mengapa mereka bisa bertikai? Sekali lagi problemnya ada pada keegoisan setiap jemaat, di mana mereka lebih mementingkan kepentingan sendiri dari pada kelompok. Bahkan problem utamanya adalah mereka terlalu dikuasai oleh emosi mereka dan ini disebabkan mereka belum menjadikan Yesus sebagai Tuhan dalam kehidupan mereka.

Jemaat Korintus mengkultuskan pemimpin manusia - gagal fokus (ay. 12). Pada ayat 12 ini memberikan penjelasan yang gamblang kepada kita tentang penyebab utama terjadinya perselisihan bahkan perpecahan di dalam jemaat Korintus. Oleh karena beberapa jemaat memilih Paulus ${ }^{17}$, yang lainnya memilih Apolos ${ }^{18}$ yang terkenal karena kefasihannya berbicara

${ }^{14}$ Siapa sebenarnya keluarga Kloe ini. Kloe sendiri mungkin adalah seorang budak perempuan yang dibebaskan dan menjadi seorang pengusaha yang cukup kaya, seorang pedagang yang agen-agennya cukup dikenal oleh Paulus. Ini hanyalah dugaan. Yang paling mungkin adalah informan-informan Paulus adalah orangorang Kristen dan mereka memberikan informasi yang lengkap tentang perkembangan-perkembangan yang menyedihkan di jemaat Korintus (bdk. Pfitzner, hlm. 26).

${ }^{15}$ R. Dean Anderson, hlm. 49.

${ }^{16}$ David E. Garland, Baker Exegetical Commentary on The New Testament: 1 Corinthians, (Grand Rapids, Michigan: Baker Academic, 2003), hlm. 43.

${ }_{17}$ "That Paul might have some in Corinth who were loyal to him is not surprising given that he spent eighteen months there, baptized some of the first members of the church, and, by his own description, was the father, planter, and builder of the community" Roy E. Ciampa dan Brian S. Rosner, The Pillar New Testament Commentary: The First Letter to The Corinthians, (Grand Rapids, Michigan, 2010), hlm. 78.

${ }_{18}$ "He is (Apollos) the one teacher who certainly followed Paul in Corinth (see Acts 18:24-28).

Moreover, he is the one to whom Paul repeatedly refers in his own response $(3: 4-9,22 ; 4: 6)$. Indeed, the most natural understanding of 4:6 is that Paul for all practical purposes has narrowed the issue in chaps. 1-4 to himself and Apollos and that Corinthians are "puffed up" in favor of the one (Apollos) against the other (Paul)". 
di depan umum bahkan berdebat dengan mereka yang melawan Injil Kristus (Kis. 18:24-28). Bahkan ada beberapa juga yang memilih Kefas ${ }^{19}$ atau Petrus yang merupakan murid yang paling dekat dengan Tuhan Yesus. Dan kelompok terakhir adalah yang masih setia kepada Yesus Kristus. Mengapa bisa terjadi demikian? R. Dean Anderson berkata,

Kita juga dapat menyimpulkan bahwa pemilihan pemimpin ini sering berhubungan dengan siapa yang telah mendidik mereka dalam iman dan membaptis mereka. Selain Apolos dan dirinya sendiri, Paulus juga menyebut Kefas (=Petrus) dan Kristus. Hubungan yang dibuatnya antara nama-nama ini dan baptisan, serta pengulangan ketiga nama pertama dalam pasal 3:22, menimbulkan dugaan bahwa Kefas pernah bekerja di Korintus. Penambahan nama "Kristus" sebagai terakhir dalam deretan 1:12, mungkin bersifat retoris, dan tidak perlu mengartikan bahwa ada juga "golongan Kristus". ${ }^{20}$

Terlepas dari apa yang dikatakan oleh Anderson di atas bahwa kemungkinan pemilihan pemimpin oleh jemaat di Korintus dilatarbelakangi oleh siapa yang telah mendidik dan membaptis mereka, namun yang perlu digarisbawahi di sini adalah telah terjadi gagal fokus dalam hal pusay penyembahan jemaat di Korintus. Idealnya, mereka harusnya menjadi golongan Kristus, namun ternyata mereka lebih mengidolakan pemimpin manusia. Mereka terpikat dengan pemimpin yang kelihatan daripada Tuhan Yesus, sang kepala gereja yang telah

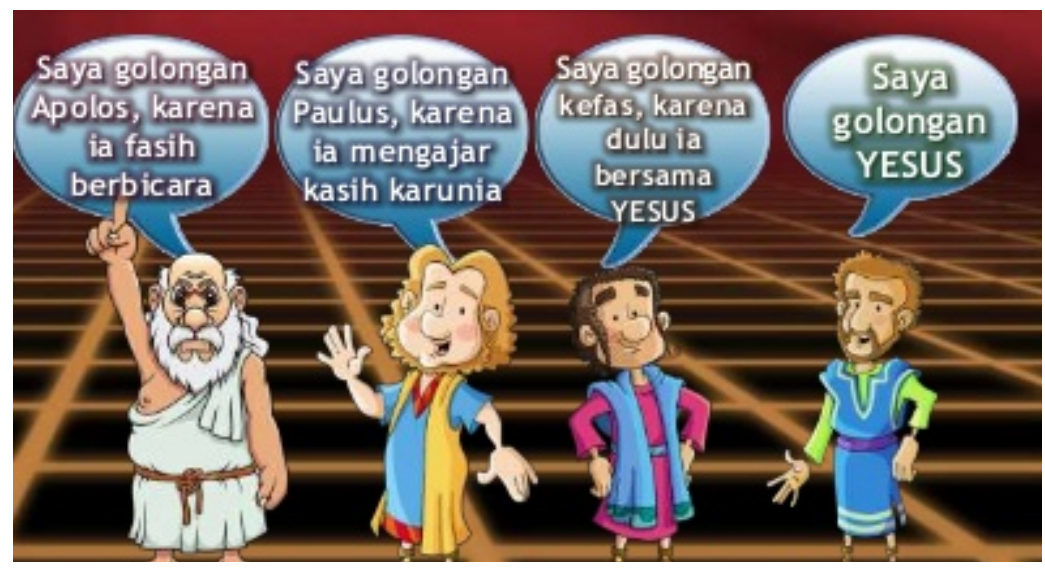
mempersatukan mereka. Gagal fokus sangat riskan dan dampaknya sangat signifikan, terbukti dengan apa yang dialami oleh jemaat Korintus.

Pertanyaan tantangan dari Paulus untuk menegaskan prinsip kesatuan dalam gereja (ay. 13). Pertanyaan tantangan Paulus yang dimaksud dalam ayat 13 adalah ketika Paulus bertanya: "Adakah Kristus terbagi-bagi? Adakah Paulus disalibkan karena kamu? Atau adakah kamu dibaptis dalam nama Paulus?' Pertanyaan pertama sebenarnya hendak berkata bahwa setiap mereka yang telah menjadi pengikut Kristus (orang Kristen) harusnya bersatu meskipun berbeda dalam latar belakang dan pendapat, karena Kristus hanya satu.

Pertanyaan kedua hendak menegaskan bahwa keselamatan atau iman yang telah diperoleh oleh setiap orang Kristen sama sekali tidak ada andil Paulus, Kefas bahkan Apolos sekalipun. Itu semata-mata hanyalah karya Kristus yang telah memberikan diri-Nya disalibkan menggantikan manusia berdosa guna mereka memperoleh keselamatan. Dan pertanyaan terakhir hendak menegaskan bahwa baptisan yang diterima oleh setiap jemaat Korintus sebagai materai atas keselamatan mereka, sekali lagi dilakukan di dalam nama Yesus Kristus.

Dari ketiga pertanyaan yang diajukan oleh Paulus ini sebenarnya menjadi petunjuk terhadap persatuan jemaat dan persatuan gereja. Atau seyogyanya jemaat di Korintus tidak akan mengalami perpecahan apabila memegang prinsip ini.

Perhatikan bagan di bawah ini!

Gordon D. Fee, The New Interantional Commentary on the New Testament: The Epistle to the Corinthians, (Grand Rapids, Michigan, 1984), hlm.56.

${ }_{19}$ The Cephas party (Cephas is the Aramaic form of the name Peter) raises difficulties of another sort. We do not know whether Peter had ever been in Corinth or not. If he had been, the basis of attachment may have been personal. But there were other considerations. Peter had been a Christian longer than Paul. He had been the leader of the Twelve. He seems to have been more ready to conform to the Jewish Law than was Paul (cf. Gal. 2:11ff.). There may have been some different emphasis in his preaching from that of Paul, though if so it must have been slight. For whether reason, a section of the Corinthians felt that there was something about Peter that made him the man to appeal to. (Leon Morris, hlm. 40-41).

${ }^{20}$ R. Dean Anderson, hlm. 49. 


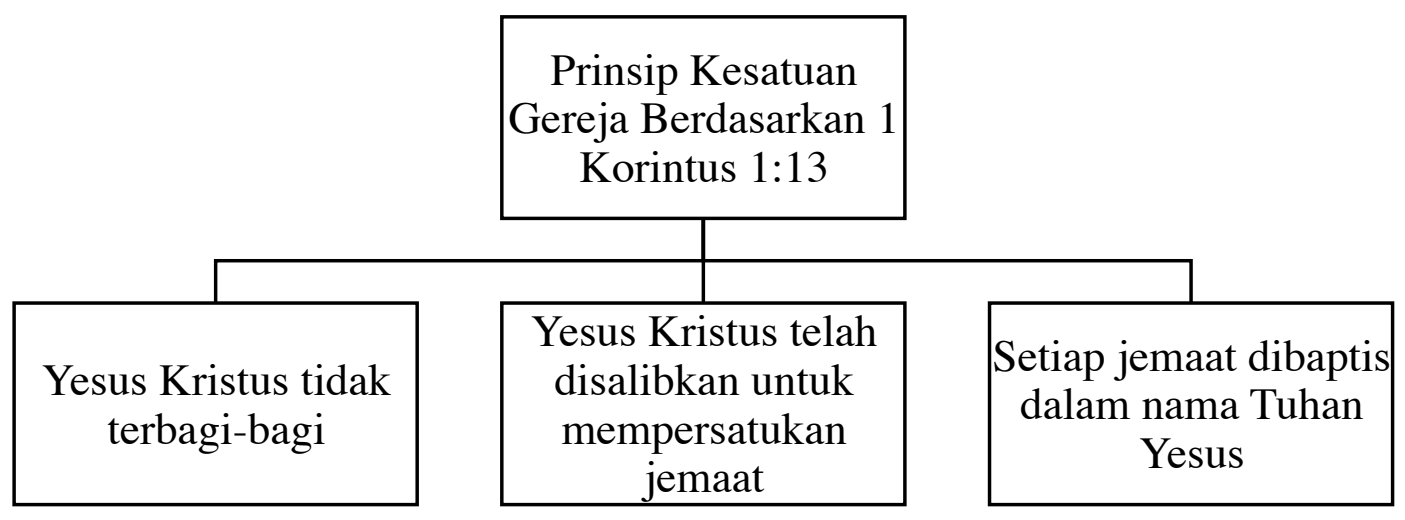

Dengan demikian, berdasarkan hasil tafsiran terhadap teks 1 Korintus 1:10-13, maka dapat dilihat dengan jelas bahwa perpecahan terjadi dalam jemaat Korintus karena adanya pergeresan dan degradasi spiritual pada jemaat Korintus. Di mana mereka lebih egois, lebih antroposentris, mengidolakan pemimpin manusia, gagal fokus dalam pusat penyembahan dan kekurangan pemahaman terhadap prinsip kesatuan gereja seperti yang dikemukakan oleh Paulus dalam ayat 13 .

\section{Kesimpulan: Solusi bagi Gereja Masa Kini}

Apabila memperhatikan permasalahan yang menyebabkan perpecahan gereja baik dalam konteks gereja modern maupun konteks gereja Korintus, maka terdapat permasalahan yang sangat identik.

\begin{tabular}{|l|l|}
\hline \multicolumn{1}{|c|}{ Gereja di Korintus } & \multicolumn{1}{|c|}{ Gereja Modern } \\
\hline $\begin{array}{l}\text { Jemaat cenderung egosentris dan } \\
\text { antroposentis, di mana lebih mementingkan } \\
\text { kepentingan kelompok dari pada } \\
\text { kepentingan bersama. }\end{array}$ & $\begin{array}{l}\text { Gereja cenderung mementingkan } \\
\text { kepentingan kelompok dan pribadi, } \\
\text { sehingga melupakan persatuan dan } \\
\text { kebersamaan - terjadi konflik kepentingan. }\end{array}$ \\
\hline $\begin{array}{l}\text { Mengkultuskan Pemimpin manusia dan } \\
\text { "melupakan" Tuhan Yesus sebagai kepala } \\
\text { Gereja. }\end{array}$ & $\begin{array}{l}\text { Gereja modern juga mengkultuskan } \\
\text { pemimpin dalam hal pemilihan ketua } \\
\text { sinode, sehingga ketika calonnya tidak } \\
\text { terpilih maka terjadilah perpecahan dan } \\
\text { konflik. }\end{array}$ \\
\hline $\begin{array}{l}\text { Gagal fokus dalam penyembahan - Tidak } \\
\text { menjadikan Yesus sebagai Tuhan dalam } \\
\text { kehidupan mereka. }\end{array}$ & $\begin{array}{l}\text { Gagal fokus dalam penyembahan karena } \\
\text { tidak lagi mengutamakan Kristus sehingga } \\
\text { mudah tersinggung, mudah konflik dan } \\
\text { lebih mengidolakan manusia dari pada } \\
\text { Tuhan Yesus. }\end{array}$ \\
\hline
\end{tabular}

Lalu apakah solusinya? Solusinya adalah: (1) Membuang sikap egois atau mementingkan kepentingan kelompok atau diri sendiri dalam kehidupan berjemaat. (2) Menghilangkan kelompok-kelompok dalam jemaat, oleh karena meskipun banyak anggota dan memiliki fungsi yang berbeda-beda namun telah dipersatukan dalam kasih Yesus. (3) Tidak mengidolakan dan mengkultuskan pemimpin manusia dalam gereja. Ingat! Kita adalah pengikut Kristus, jadi kita harus selalu menjadikan Kristus yang prioritas, yang utama dan yang penting dalam setiap aspek hidup kita.

\section{E. Literatur}

Simanjuntak, BA, "Budaya Konflik Krisis HKBP dan Kelengahan Strategis", Gereja Di Pentas Politik, Binar Sitompul, Rainy Hutabarat (Ed.), Jakarta: Yakoma-PGI, 1997.

Douglas.D., Ensiklopedi Alkitab Masa Kini: Jilid I (A-L), Jakarta: Yayasan Bina Kasih/OMF. 1992.

Pfitzner, V.C., Ulasan atas 1 Korintus: Kesatuan dalam Kepelbagaian, Jakarta: BPK Gunung Mulia, 2008. 
Morris, Leon, Tyndale New Testament Commentaries: 1 Corinthians, Grand Rapids, Michigan, 1993 (Revised Edition).

Anderson, R. Dean, Tafsiran Perjanjian Baru: Surat 1 Korintus, Surabaya: Momentum, 2018.

Garland, David E., Baker Exegetical Commentary on The New Testament: 1 Corinthians, Grand Rapids, Michigan: Baker Academic, 2003.

Ciampa, Roy E., dan Brian S. Rosner, The Pillar New Testament Commentary: The First Letter to The Corinthians, Grand Rapids, Michigan, 2010.

Fee, Gordon D., The New Interantional Commentary on the New Testament: The Epistle to the Corinthians, Grand Rapids, Michigan, 1984.

https://tulussudarto.wordpress.com/2007/09/28/perpecahan-gereja-2/

https://tulussudarto.wordpress.com/2007/09/28/perpecahan-gereja-2/

https://id.wikipedia.org/wiki/Skisma_Barat//

https://id.wikipedia.org/wiki/Reformasi_Protestan//

https://tulussudarto.wordpress.com/2007/09/28/perpecahan-gereja-2/

https://ketarenwydia.blogspot.com/2018/05/makalah-sejarah-berdirinya-gkpi-gereja.html 